\title{
LEED Sertifikalı Ofis Binalarının Enerji ve Atmosfer Kriteri Açısından Değerlendirilmesi: Maslak Bölgesi Örneği
}

\author{
Evaluation of LEED Certified Office Buildings in Terms of \\ Energy and Atmosphere Criteria: The Case of Maslak Region
}

\author{
${\text { İbrahim } \text { Erol }^{1 *} \text {, Gözde Çakır Kıasıf }}^{2}$
}

Geliş / Received:27/02/2021

Revize / Revised:21/04/2021

Kabul / Accepted:26/04/2021

\section{ÖZ}

Dünyadaki enerji tüketiminin $\% 50$ 'si ve fosil yakıt tüketiminin $\% 40$ '1 yapı yaşam döngüsü süreçlerinde ortaya çıkmaktadır. Aynı zamanda bu süreçler, sera gazı etkisi oluşturan maddelerin salınımının \%50'sini ve toplam hava kirliliğinin \%24'ünü oluşturmaktadır. Bu anlamda, yapıların enerji ve atmosfer ile olan ilişkileri, tüm canlılar için hayati bir önem taşımaktadır. Dünyada birçok disiplin, çevresel sorunların azaltılması konusunda çalışmalar yürütmektedir. Bu çalışmaların bir neticesi olarak ortaya çıkan sürdürülebilirlik ve sürdürülebilir mimarlık kavramı, yapı sektörünün çevresel etkilerinin tartışılmasına olanak sağlamıştır. Bu kapsamda, mimari ürünlerin sürdürülebilirlik düzeylerinin ölçülmesini hedefleyen çeşitli sertifikalandırma sistemleri geliştirilmiştir. $\mathrm{Bu}$ sistemlerden biri olan ve ülkemizde de yaygın olarak kullanılan LEED yeşil bina sertifikalandırma sistemi, puanlama sisteminde Enerji ve Atmosfer kriterine büyük bir pay ayırmıştır. Çalışmanın amacı Maslak’taki LEED sertifikalı ofis yapılarının Enerji ve Atmosfer kriteri bakımından sahip oldukları güçlü ve zayıf yönleri ortaya koyarak durum analizi yapmak ve iyileştirici-geliştirici önerilerde bulunmaktır. Bu kapsamda Alsar Maslak No:1, Orjin Maslak, Maslak Link Plaza, Olive Plaza ve Uniq İstanbul projeleri 'Enerji Performansının Optimize Edilmesi', 'Yerinde Yenilenebilir Enerji Kullanımı', 'Gelișmiș Yapılandırma', 'Gelișmiș Soğutma Yönetimi', ‘Ölçüm ve Onaylama (Temel Bina-Kiracı Alt Ölçümü)' ve 'Yeşil Güç' açısından değerlendirilmiştir. Elde edilen bulgularda Enerji ve Atmosfer kriteri açısından Orjin Maslak Binasının en yüksek puanı (18/37), Olive Plaza'nın ise en düşük puanı (8/37) aldığı görülmüştür. Diğer üç bina 37 üzerinden 16 puan alarak aynı performansı sergilemişlerdir. Tüm bina ortalamaları üzerinden ele alındığında ise 'Gelişmiș Soğutma Yönetimi' ve 'Ölçüm ve Onaylama (Temel Bina - Kiracı Alt Ölçümü)' kredilerinde \%80 ile en başarılı olunduğu, daha sonra \%60 ile 'Gelişmiş Yapılandırma' kredisinin yerine getirildiği görülmüştür. 'Enerji Performansının Optimize Edilmesi (\%34)' ve 'Yeşil Güç (\%20)' kredilerinde istenilen performansın elde edilemediği 'Yerinde Yenilenebilir Enerji' kriterinin ise hiç kullanılmadığı ortaya konmuştur.

\section{Anahtar Kelimeler-Sürdürülebilirlik, Ofis Yapıları, LEED, Enerji ve Atmosfer}

\footnotetext{
ABSTRACT

$50 \%$ of the energy consumption in the world and $40 \%$ of the fossil fuel consumption occur in the building life cycle processes. At the same time, these processes constitute $50 \%$ of the release of substances that create greenhouse gas effects and $24 \%$ of the total air pollution. In this sense, the relationship of structures with energy

1*Sorumlu yazar iletişim: ibrahimerol.arc@gmail.com (https://orcid.org/0000-0002-3092-7128)

Tasarım Bölümü, İstanbul Gelişim Meslek Yüksekokulu, İstanbul Gelişim Üniversitesi, İstanbul, Türkiye

2İletișim: gozdecakir@halic.edu.tr (https://orcid.org/0000-0002-7734-4990)

Mimarlık Bölümü, Haliç Üniversitesi Mimarlık Fakültesi, İstanbul, Türkiye
} 
and atmosphere is of vital importance for all living things. Many disciplines around the world work on reducing environmental problems. The concept of sustainability and sustainable architecture, which emerged as a result of these studies, made it possible to discuss the environmental effects of the building sector. In this context, various certification systems aimed at measuring the sustainability levels of architectural products have been developed. One of these systems, the LEED green building certification system, which is widely used in our country, has allocated a large share to the Energy and Atmosphere criteria in the scoring system. The study aims to analyze the situation by revealing the strengths and weaknesses of the LEED-certified office buildings in Maslak in terms of Energy and Atmosphere criteria and to make suggestions for improvement. The study aims to analyze the situation by revealing the strengths and weaknesses of the LEED-certified office buildings in Maslak in terms of Energy and Atmosphere criteria and to make suggestions for improvements and improvements. In this context, Alsar Maslak No: 1, Orjin Maslak, Maslak Link Plaza, Olive Plaza, and Uniq Istanbul projects have been evaluated in terms of 'Optimize Energy Performance', 'On-Site Renewable Energy', 'Enhanced Commissioning', 'Enhanced Refrigerant Mgmt', 'Measurement and Verification (Base Building- Tenant Submetering)' and 'Green Power'. In the findings obtained, it was seen that Orjin Maslak Building received the highest score (18/37) and Olive Plaza received the lowest score (8/37) in terms of Energy and Atmosphere criteria. The other three buildings scored 16 out of 37, performing the same. Considering all the building averages, it is seen that the 'Enhanced Refrigerant Mgmt' and 'Measurement and Verification (Base Building- Tenant Submetering)' credits are the most successful with $80 \%$, and then the 'Enhanced Commissioning' loan is fulfilled with $60 \%$. It has been revealed that the desired performance could not be achieved in "Optimize Energy Performance (34\%)" and "Green Power (20\%)" and the 'On-Site Renewable Energy' criterion was never used.

\section{Keywords- Sustainability, Office Buildings, LEED, Energy and Atmosphere}

\section{GíRiş}

Mimarlık disiplini, yapı yaşam döngüsünün tüm süreçlerinde diğer birçok disiplinle birlikte hareket etmektedir. $\mathrm{Bu}$ süreçlerde ciddi bir enerji ve kaynak tüketimi meydana gelmektedir. Enerji ve kaynak tüketimlerinin neden olduğu ekonomik ve çevresel sorunlara, sürdürülebilirlik kavramının ortaya çıkması ile insanı merkezine alan çözüm önerileri getirilmiştir. Mimarlık disiplini de birlikte hareket ettiği, hatta üzerinde etkili olduğu diğer disiplinlerin sürdürülebilir çözümler üretebilmesine öncülük edebilmektedir. Bu anlamda, yeşil bina kavramı, sürdürülebilir mimarlık açısından önemli bir gelişme olarak kabul edilebilmektedir. Dünyanın birçok ülkesinde yaygınlaşan yeşil bina sertifika sistemleri ise, binaların çeşitli kategorilerde ve birçok alt kritere göre değerlendirilmesine olanak sağlamaktadır. Leadership in Energy and Environmental Design (LEED-Enerji ve Çevre Tasarımında Liderlik) yeşil bina sertifika sistemi, ülkemizde sıklıkla tercih edilmektedir. LEED; arazi kullanımı, su verimliliği, malzeme ve kaynaklar, enerji ve atmosfer, inovasyon ve bölgesel öncelik gibi birçok kriter üzerinden binaları derecelendirmektedir. LEED'in değerlendirme süreci içerisinde yer alan enerji ve atmosfer; sosyal, çevresel ve ekonomik anlamda binaların sürdürülebilirliğinde büyük bir öneme sahiptir. Enerji ve atmosfer kategorisi; işletmeye alma, enerji kullanımını gözlemleme, verimli tasarım ve yapım, verimli uygulamalar, verimli sistemler ve aydınlatma uygulamaları, yenilenebilir ve temiz enerji kaynaklarının kullanımı, saha içinde veya dışında enerji üretimi ve diğer yenilikçi stratejiler gibi çok çeşitli enerji stratejilerini teşvik etmektedir [1]. Bu anlamda, araştırma kapsamında günümüzde ofis binalarının yoğunlaştığ Maslak Bölgesi özelinde ele alınan LEED sertifikalı ofis binalarının, enerji ve atmosfer kategorisinden aldıkları puanlar değerlendirilerek karşılaştırılmaktadır. Araştırmanın sağlıklı bir zeminde yapılabilmesi ve değişkenlerin doğru bir şekilde değerlendirilebilmesi için yalnızca 'çekirdek ve kabuk' kategorisinde sertifika alan ofis binaları araştırma kapsamına alınmaktadır. Araştırma verilerinin elde edilmesinde literatür taramasına dayalı bir yöntem izlenerek; binalarla ilgili skor tabloları ve alt kriterlere ait bilgilere, LEED'in resmi online veritabanı / web sayfası üzerinden ulaşılmaktadır [2]. Elde edilen veriler, oluşturulan tablolar üzerinden detaylı bir şekilde değerlendirilerek puan kaybına neden olan unsurlar ortaya konulmaktadır. Araştırmanın amacı, Maslak Bölgesindeki LEED Sertifikalı ofis yapılarının enerji ve atmosfer kategorisinde almış oldukları puanlar üzerinden kullanılan yöntemleri incelemek, üstün ve zayıf yönlerini ortaya koymak ve çözüme yönelik öneriler geliştirmektir. Geliștirilen öneriler neticesinde, yapıların sürdürülebilirliği üzerinde önemli bir paya sahip olan enerji ve atmosfer kategorisindeki eksiklikler giderilebilecek, binaların sertifikasyon süreçlerinde daha başarılı sonuçlar elde edilebilecek ve diğer ofis yapılarına sürdürülebilirlik anlamında örnek teşkil edebilecektir. 


\section{OFIS KAVRAMI}

Mimari, tasarımsal ve sosyolojik bir olgu olan ofis, en genel tanımı ile insanların birlikte veya tek olarak çalıştığı oda ya da alana verilen addır. Scognamillo'ya göre ofis, bir işin yapıldı ğı, bir uğraşın sürdürüldüğ̈̈ yerdir [3]. Bu tanım, sadece bir avukat ya da işadamının çalışma alanı, bir banka ve dükkan değil; bir yontucu stüdyosu, bir kokteyl bar, bir doktor muayenesi ve ya bir karakol gibi birçok mekanı da kapsamaktadır. Mitchell'e göre ise günümüz ofisinin tanımı, sayısız belgenin, hesabın ve görsel malzemenin toplandığı, depolandığı, iletildiği ve dağıtıldığı, bilgiye dayalı işlerin özelleştirilmiş mekanıdır [3]. "Tasarım uzmanı Francis Duffy, ofis mekânlarının tarihsel gelişimini; Ev mekanları dönemi (1849-1864), Gökdelen kağıt fabrikaları (1894-1904), Ortak kontrol dönemi (1954-1963) ve Endüstriyel demokrasi dönemi (1973 ve sonrası) olmak üzere dört kısımda incelemiştir" [4].

İlk ofis örneklerinin gelişimi, günümüzdeki kadar hızlı olmasa da, teknolojiyle (elektrik, daktilo ve telefon gibi) paralel olarak değişim göstermiştir [5]. Sanayileşme ile artan çalışan sayısı ve ikinci dünya savaşı sonrasında geliştirilen ısıtma, havalandırma ve iklimlendirme teknolojileri, ofis tasarımlarını daha ekonomik hale getirmiştir. Gelişen teknolojiler sayesinde ofis çalışanlarının pencerelere yakın konumlandırılması gerekliliği ortadan kalkmıştır [6]. Bu durum, geçmişten günümüze, geleneksel ofis plan tiplerinin çeşitlenmesinde oldukça etkili olmuştur.

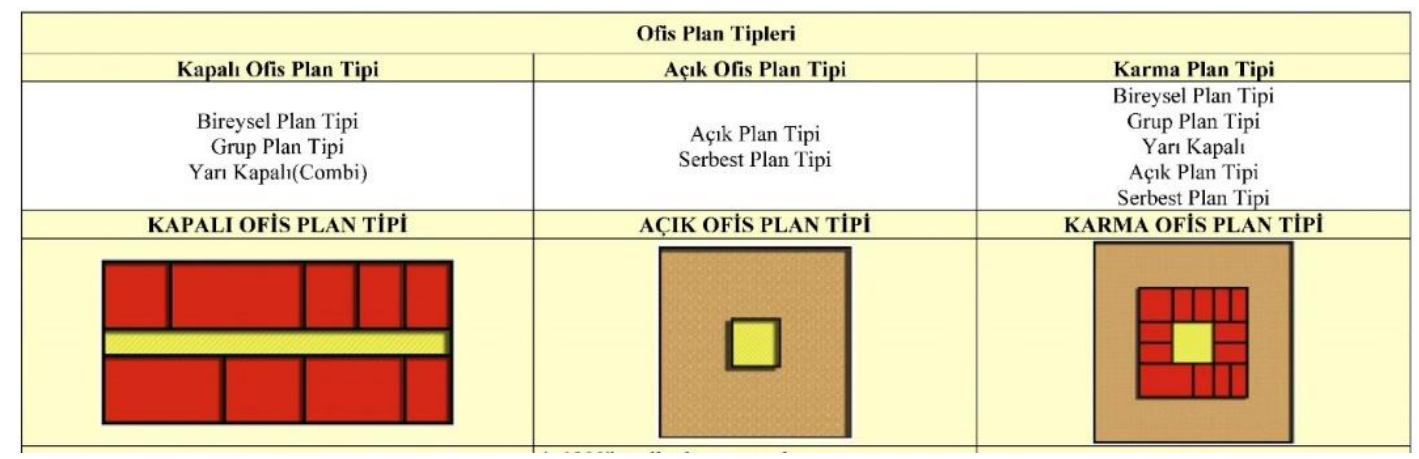

Şekil 1. Ofis Plan Tipleri [7]

Geleneksel ofis plan tipleri, Kapalı, Açık ve Karma plan tipi olmak üzere üç başlık altında incelenebilmektedir. Kapalı ofis plan tipi, Ortaçağ'da örnekleri görülebilecek olan en eski plan tiplerindendir. Bölücü duvarlar ile ayrılan hücre şeklindeki mekanların bir koridor etrafında dizildiği kapalı ofis plan tipinde, doğal ışık kullanımı esas olduğu için mekan derinlikleri 5-6 metre ile sınırlandırılmak durumundadır. Hücre yapısı nedeni ile çalışanlar arasındaki iletişim fiziksel olarak kısıtlıdır ve takım çalışmaları için elverişli değildir. Yapısı itibarı ile mekansal değişikliklerin mümkün olmaması, kapalı ofis plan tipinin esneklikten yoksun olduğunu göstermektedir. Açık ofis plan tipi, 20. Yüzyılın başlarında ortaya çıkmaya başlayan ve çalışma mekanları arasındaki ayrımın bölücü elemanlar / mobilyalar aracılığı ile gerçekleştirildiği, kapalı ofis plan tipine göre nispeten daha esnek bir kullanıma sahip olan plan tipidir. İşlevsel esneklik aynı şekilde mekan derinliklerinde de görülmektedir. Açık ofis plan tipi, takım çalışmalarına elverişli olmakla birlikte, çalışanlar arasındaki iletişimi de arttırmaktadır. Bireysel, grup, yarı kapalı, açık ve serbest plan tiplerinin işlevsel ihtiyaçlara göre birlikte çözümlendiği plan tipi olan karma plan tipinin, günümüzde birçok yapıda tercih edildiğini söylemek mümkündür.

\section{ENERJI VE ATMOSFER, SÜRDÜRÜLEBİLIRLIK, LEED}

Günümüzde, inşaat teknolojilerinde yaşanan gelişmeler, büyük ölçekli projelerin hayata geçirilmesini kolaylaştırmaktadır. Ülkemizde son yıllarda artan yapılaşma faaliyetleri göz önünde bulundurulduğunda, binaların yapım ve işletme süreçlerinin çevresel etkileri tartışma konusu haline gelmiştir. "Küresel anlamda, kullanılan enerjinin \%50'si, suyun \%42si, ahşap üretiminin \%25'i ve fosil yakıtların \%40'ı yapılaşma faaliyetleri için kullanılmaktadır. Bununla birlikte, $\mathrm{CO}_{2}$ ve sera etkisine neden olan diğer gazların toplam üretiminin \%50'si, içme suyu kirliliğinin \%40’1 ve hava kirliliğinin \%24'ü yapılaşma faaliyetlerinde atık olarak ortaya çıkmaktadır” [8]. Eryıldız'ın da belirttiği gibi, yapılaşma faaliyetlerinin doğa ve atmosfer üzerindeki olumsuz etkileri oldukça fazladır. Ancak, enerji kullanımı, fosil yakıt tüketimi ve gaz salınımları yapılaşma sürecinin tamamlanmasından sonra da devam etmektedir. Bu anlamda, inşa edilen/edilecek binaların yaşam döngüsünün tüm evrelerinde; enerji 
sistemleri, enerji kaynakları, gaz salınımları, enerji verimliliği gibi unsurlar enerji ve atmosfer açısından önem taşımaktadır.

Günümüzde birçok disiplin çevresel sorunların çözümü ve enerji yönetimi konusunda çeşitli çalışmalar yürütmektedir. Çok daha eski bir tarihten itibaren tartışma konusu haline gelen sürdürülebilirlik kavramı, tüm disiplinler için bu sorunların çözümüne yönelik araştırmaların ve çalışmaların ortak merkezi haline gelmiştir. Sürdürülebilirlik, doğal kaynakları tüketmeyen, ekonomi ile ekosistem arasındaki dengeyi koruyan, gelecek kuşakların gereksinmelerini karşılayabilme olanaklarını ellerinden almayan, ekolojik açıdan sürdürülebilir nitelikte olan kalkınma olarak tanımlanmaktadır [9]. Sürdürülebilir kalkınma, birçok disiplinde tartışılan bir kavram olarak sosyal, ekonomik ve çevresel anlamda mimarlık disiplini tarafından da tartışılmaktadır.

Dünya genelinde, mimari ürünün sürdürülebilir olmayı ne düzeyde sağladığını ölçebilmek amacıyla çeşitli sertifikalandırma sistemleri geliştirilmiştir. Bu sertifikalandırma sistemlerine genel olarak "Yeşil Bina Sertifikalandırma" sistemleri adı verilmektedir [9]. Aynı amaç doğrultusunda hareket eden bu sertifikalandırma sistemleri ülkeden ülkeye değişiklik gösterebilmektedir. Dünya'nın birçok ülkesinde faaliyet gösteren çok sayıda sertifikalandırma kuruluşları bulunmaktadır.
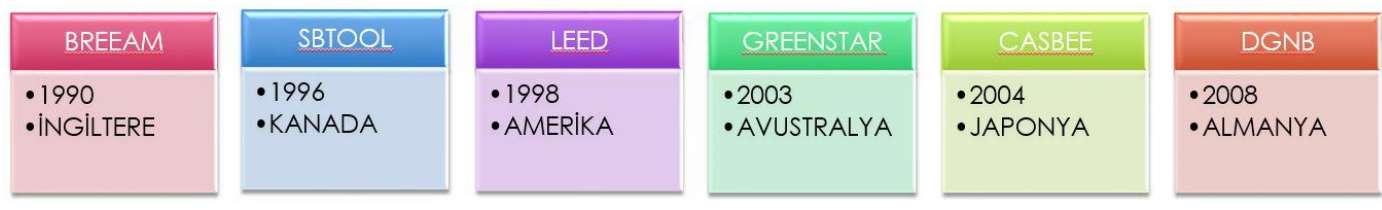

Şekil 2. Yeşil Bina Sertifikalandırma Sistemlerinden Bazıları

En çok bilinen ve görece daha gelişmiş olarak kabul edilebilecek olan sertifikasyon sistemlerinin başlıcaları Şekil 2'de görüldüğü gibi: İngiltere'de BREAM (Building Research Establishment Environmental Assessment Method - Bina Araştırma Kurumu Çevresel Değerlendirme Metodu), Kanada'da SBTOOL (Sustainable Building Tool - Sürdürülebilir Bina Arac1), Amerika'da LEED (Leadership in Energy and Environmental Design - Enerji ve Çevre Tasarımında Liderlik), Avustralya'da GREEN STAR (Yeşil Yıldız), Japonya'da CASBEE (Comprehensive Assessment System for Building Environmental Efficiency - Binaların Çevresel Etkinliği için Detaylı Değerlendirme Sistemi) ve Almanya'da DGNB (Deutsche Gesellschaft für Nachhaltiges Bauen - Alman Sürdürülebilir Bina Konseyi Sistemi) olmak üzere kuruluş yıllarına göre sıralanabilmektedir. "Yeşil bina sertifika sistemleri, binayı ürün bazında taşımış bulunduğu "yeşil" olma niteliklerinin ne düzeyde yeterli olduğu konusundaki görecelilikten kurtarmakta, ürüne gerçeklik kazandırmakta, ölçülebilir ve değerlendirilebilir hale getirerek yapı sektörü ve ilgili kişiler açısından kolay anlaşılabilir ve tanımlanabilir kılmaktadır. [9]. Böylece, (yeşil) binalar, sürdürülebilir mimarlık kavramının somutlaştırılmış bir örneğini temsil edebilecek noktaya gelebilmektedirler. Günümüzde, dünyanın birçok yerinde faaliyet gösteren sertifikasyon sistemleri, birbirilerinden bağımsız olarak özgün değerlendirme kriterlerine sahiptir. Puanlama sisteminde enerji ve atmosfer kriterine büyük bir yer ayıran ve ülkemizde yaygın olarak tercih edilmekte olan LEED sertifikasyon sistemi, araştırma kapsamında incelemeye değer görülmüştür.

Amerikan Yeşil Bina Konseyi - USGBC (United States Green Building Council) tarafindan oluşturulan LEED sertifika süreci ilk olarak Amerika'da kullanılmaya başlanmıştır. "LEED yeşil bina sertifika sistemi güncellemelere açık ve esnek bir niteliğe sahiptir. İlk olarak, 1998 yılında LEED v.1.0 olarak kullanıma sunulmuştur. Kısa süre sonra 2000 yılında LEED v.2.0 sertifika sistemi ile güncelleme gerçekleştirilmiştir” [9]. Daha sonra sistem 2009 yılında LEED v.3.0 ve 2014 yılında LEED v.4.0 olarak güncellenmiştir.

Özcan (2013), LEED sertifikalandırma sürecini şu şekilde açıklamıştır:

"Sistem, USGBC organizasyonu başkanlığında, LEED Technical Committee (Teknik Komite) ve LEED Steering Committee (İcra Komitesi) tarafından yürütülmektedir. Değerlendirme sürecine gönüllülük esasına bağlı olarak yapılan başvuru ve projenin sisteme kaydedilmesi ile başlanır. Projeye ait inşaat kayıtları, tüm mühendislik hesaplamaları, enerji modellemesi raporu, projeye ait tüm çizim, diyagram ve yazılı açıklamalar internet üzerinden LEED'e teslim edilir. Gerekli incelemenin ardından ön koşul ve kriterleri sağlayan proje değerlendirme sürecine alınır. Değerlendirme sürecinde, yapı türüne bağlı olarak özel olarak geliştirilmiş puanlama sistemi, yapı üzerine uygulanarak yapıya ait toplam yeşil bina değeri hesaplanır. Hesaplama sonucunda yapıya ait toplam puan, sertifikalandırma sistemine ait değerlendirme tablosunda uygun bulunan sertifika tipi ile sertifikalandırılır. 
Sertifika belgesi düzenlenir ve başvuru sahiplerine sunulur. Başvuru, değerlendirme süreci ve sertifika almaya hak kazanan yapılar için sertifika belgesinin hazırlanması ortalama altı aylık bir zamanı kapsamaktadır" [9].

LEED v.3.0 versiyonunda; Yeni Yapılar (LEED-NC), Mevcut Yapılar (LEED-EB), Ticari İç Mekanlar (LEED-CI), Çekirdek ve Kabuk (LEED-CS), Okullar (LEED-S), Sağlık Yapıları (LEED-H), Konutlar (LEEDHomes) ve Mahalle Gelişimi (LEED-ND) olmak üzere çeşitli yapı türleri için denetleme sistemleri oluşturmuştur [10;11]. Araştırma kapsamında değerlendirilecek uygulama örnekleri, aynı kriterler üzerinden karşılaştırılabilmesi için, LEED 2009 v.3.0 sürümü ve 'Çekirdek ve Kabuk' sınıfinda sertifikalandırılan binalar olarak belirlenmiştir. LEED her yapı sınıfı için farklı değerlendirme kriterleri geliştirmiştir. Çekirdek ve Kabuk olarak sınıflandırdığı yap1 türündeki binaları, Şekil 3'te de görüldüğü üzere; Sürdürülebilir Araziler (Sustainable Sites), Su Verimliliği (Water Efficiency), Enerji ve Atmosfer (Energy and Atmosphere), Malzeme ve Kaynaklar (Materials and Resources), İç Ortam Kalitesi (Indoor Enviromental Quality), İnovasyon (Innovation), Bölgesel Öncelik (Regional Priority), Yerleşim ve Ulaşım (Location and Transport) olmak üzere 7 kriter üzerinden değerlendirmektedir.

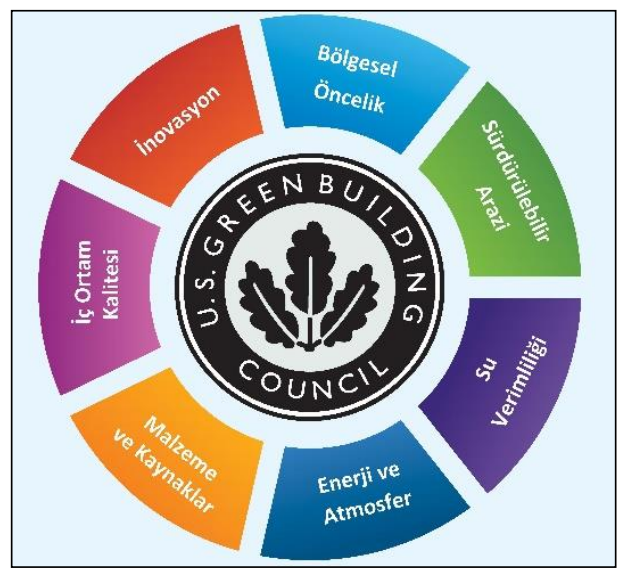

Şekil 3. LEED Değerlendirme Kriterleri [12].

$\mathrm{Bu}$ sistemde binalar, değerlendirme kriterlerinin her birinin alt kriterlerinden gelen krediler ile genel bir skor elde etmektedirler. Tüm kriterlerden aldıkları puanlar toplanarak binanın skoru / toplam puanı belirlenmektedir.

Tablo 1. Bina toplam puanlarına göre kazanılacak olan sertifika türleri.

\begin{tabular}{lc}
\hline Toplam Puan & Sertifika Türü \\
\hline $40-49$ & Sertifikalı \\
$50-59$ & Silver \\
$60-79$ & Gold \\
$80-110$ & Platinum \\
\hline
\end{tabular}

Tablo 1'de görüldüğü gibi, 40 puanın altındaki binalar sertifikalandırılmamakta, toplam puanı 40-49 arasında olan binalar ise derecesiz olarak sertifikalandırılmaktadır. Toplam puanı 50-59 arasında olan binalar LEED Silver; 60-79 arasında olan binalar LEED Gold, 80-110 arasında olan binalar ise LEED Platinum derecesi ile sertifikalandırılmaktadır [10-13].

Tüm kriterlerden tam puan alınması durumunda bina 110 puana ulaşabilmektedir. Kriterlerin 110 tam puanı üzerindeki puan dağılımları ise Tablo 2'de verilmiştir: 


\begin{tabular}{|c|c|c|}
\hline & $\begin{array}{l}\text { BŞEÜ Fen Bilimleri Dergisi } \\
8(1), 322-335,2021\end{array}$ & $\begin{array}{r}\text { BSEU Journal of Science } \\
\text { https://doi.org/10.35193/bseufbd.887581 }\end{array}$ \\
\hline $\begin{array}{l}\text { BiLECEIK SEYH EDEBALI } \\
\text { UNIVERSITESI }\end{array}$ & & 2458-7575 (https://dergipark.org.tr/tr/pub/bseufbd) \\
\hline
\end{tabular}

Tablo 2. Değerlendirme kriterlerinin puan dağılımları.

\begin{tabular}{clc}
\hline & Kriterler & Puan Dağılımları \\
\hline 1. & Sürdürülebilir Araziler & $28 / 110$ \\
2. & Su Verimliliği & $10 / 110$ \\
3. & Enerji ve Atmosfer & $37 / 110$ \\
4. & Malzeme ve Kaynaklar & $13 / 110$ \\
5. & İç Ortam Kalitesi & $12 / 110$ \\
6. & İnovasyon & $6 / 110$ \\
7. & Bölgesel Öncelik & $4 / 110$ \\
\hline
\end{tabular}

Araştırma kapsamında değerlendirilen 'Enerji ve Atmosfer' kriterinin, 37 puan ile toplam puan / skor içerisinde en büyük paya sahip olduğu görülmektedir. LEED Enerji ve Atmosfer değerlendirmesini, 3 ön koşul ve 6 başlıktan oluşan alt kredilere dayandırmaktadır. Ön koşullardan ilki, binanın henüz tasarım aşamasında iken belirlenen işletmeye geçiş süreci ile ilgili şartların yerine getirilmesini amaçlayan 'Temel Bina Enerji Sistemlerinin Kullanılması'dır. İkinci ön koşul olan 'Minimum Enerji Performansı' ise binalarda minimum enerji harcayarak maksimum verim almayı hedeflemektedir. $\mathrm{Bu}$ koşulun sağlanmasında enerji maliyet bütçelerinin tasarım aşamasında iken belirlenmesi büyük bir öneme sahiptir. Üçüncü ve son ön koşul olan 'Temel Soğutma Yönetimi', binaların soğutma sistemlerinde kullanılan ve ozon tabakasına zarar veren Kloroflorokarbonların (CFCs) yapıdan uzaklaştırılmasını, hatta kullanılmamasını gerektirmektedir. Eğer mevcut durumda kullanımda ise, bu ön koşulun sağlanabilmesi için, bu maddenin binadan kaldırılması ile ilgili geleceğe yönelik bir planlama sunulması gerekmektedir. LEED, bu üç ön koşulun sağlanması durumunda, binaları Tablo 3 'te verilmiş olan 'Alt Krediler' ile ‘Enerji ve Atmosfer Kriteri’ bakımından değerlendirmektedir.

Tablo 3. Enerji ve atmosfer kriterinin alt kredilerine ait puan ağırlıkları ve oranlar.

\begin{tabular}{lllcc}
\hline & & \multicolumn{1}{c}{ Alt Krediler } & \multicolumn{2}{c}{ Enerji ve Atmosfer Kriteri İçerisindeki } \\
\cline { 3 - 5 } & & \multicolumn{1}{c}{ Puanı } & Oranı \\
\hline EAc1 & Kredi 1 & Enerji Performansının Optimize Edilmesi & $\mathbf{2 1 / 3 7}$ & $57 \%$ \\
EAc2 & Kredi 2 & Yerinde Yenilenebilir Enerji & $\mathbf{4 / 3 7}$ & $11 \%$ \\
EAc3 & Kredi 3 & Gelişmiş Yapılandırma & $\mathbf{2 / 3 7}$ & $5 \%$ \\
EAc4 & Kredi 4 & Gelişmiş Soğutma Yönetimi & $\mathbf{2 / 3 7}$ & $5 \%$ \\
EAc5.1 & Kredi 5.1 & Ölçüm ve Onaylama - Temel Bina & $\mathbf{3 / 3 7}$ & $8 \%$ \\
EAc5.2 & Kredi 5.2 & Ölçüm ve Onaylama - Kiracı Alt Ölçümü & $\mathbf{3 / 3 7}$ & $8 \%$ \\
EAc6 & Kredi 6 & Yeşil Güç & $\mathbf{2 / 3 7}$ & $5 \%$ \\
\hline
\end{tabular}

Enerji performansının optimize edilmesi kredisi, 21 puan ile Enerji ve Atmosfer toplam puanının \%57'sini, yerinde yenilebilir enerji \%11'ini, Ölçüm ve onaylama ise \%8'ini oluşturmaktadır. Gelişmiş̧ yapılandırma, gelişmiş soğutma yönetimi ve yeşil güç kredileri ise sahip olduklar 2'şer puanlık dilimleri ile enerji ve atmosfer puanına her biri $\% 5$ 'lik etki etmektedirler.

'Enerji Performansının Optimize Edilmesi', hem Enerji ve Atmosfer kategorisinin hem de LEED sisteminin en yüksek puanına (21 puan) sahip olan bir kredidir. Enerji performansı, binanın dış kabuğunu, havalandırma unsurlarını, güç dağıtım ve aydınlatma sistemlerini kapsamaktadır. Bu başlık altında puan alınabilmesi, yapıların enerji simülasyonlarının geliştirilmesi ile doğrudan ilişkilidir.

Ağılıklı puan olarak ikinci sırada yer alan 'Yerinde Yenilenebilir Enerji', binalardaki enerji kaynaklarının yenilenebilirlikleri ile ilgilidir. Üretilen enerjinin binanın yıllık enerji maliyeti içindeki yüzdesi arttıkça, bu başlık altında daha fazla puan kazanılabilmektedir.

Üçüncü sırada yer alan 'Gelişmiş Yapılandırma', bu kategorinin ilk ön koşulu olan "Temel Bina Enerji Sistemlerinin Kullanımı"nın, enerji sistemi tasarımlarının ve girişimci sunumlarının incelenmesi, yapı operatörleri için elle kontrol edilebilen sistemler oluşturulması, ayrıca çalışanların eğitiminin ve performansının 
doğrulanabilmesi için 10 aylık kullanma süresi boyunca yapı operasyonlarının yeniden denetlenmesini kapsayacak şekilde geliştirilmesini hedeflemektedir.

'Gelişmiş Soğutma Yönetimi' ise, binalarda bulunan soğutma unsurlarının ozon tabakasına etkisinin değerlendirilmesini, zararlı maddelerin kullanımının azaltılmasını ve hatta mümkünse tamamen engellenmesini esas almaktadır. Bu kapsam atılan adımlar ile ozon tabakasına zarar verebilecek etkenler ortadan kaldırılabilmekte ve yapılan ölçümlere göre puan kazanılabilmektedir.

'Ölçüm ve Onaylama' kredisi, aslında binalardaki operasyonel etkilerin başlangıçta belirlenen tüketim miktarları ile uyumunun ölçümüne yönelik geribildirimler sunan bir sensör sisteminin kurulmasını kapsamaktadır.

Son olarak, yenilenebilir enerji kullanımının bir devamı niteliğinde olan 'Yeşil Güç', binanın enerji ihtiyacının \%35'lik bir kısmının iki yıl boyunca yeşil enerji üretebilen kaynaklardan sağlanmasını amaçlamaktadır.

Çalışmanın kapsamı ve yönteminin belirlenmesinde Türkiye'deki benzer çalışmalar incelenip detaylı bir literatür taraması yapıldığında;

- Gürgün (2017) tarafından yapılan çalışmada Türkiye'deki LEED NC 2009 Sertifikalı 78 adet binayı 'Enerji ve Atmosfer' kriterinden aldığı puanlar bağlamında incelediği görülmüştür. Bu çalışmada binalar arasında herhangi bir karşılaştırma yapılmamıştır. Sadece puanların kazanılmasında kullanılan uygulamalar ile puanların kaybedilme nedenleri üzerinde durulmuştur [14].

- Saka (2011) ortaya koyduğu çalışmada İTÜ ARI Teknokent Kuluçka Merkezinin sürdürülebilirliğini LEED Sertifikasına ait yedi kriter üzerinden ele almıştır. İçlerinde Enerji ve Atmosfer kriterinin de bulunduğu diğer kriterler Sürdürülebilir Arazi, Su Verimliliği, Malzeme ve Kaynaklar, İç Mekan Hava Kalitesi, Tasarımda Yenilik ve Yerel Öncelik’tir. Çalışma, yukarıda ismi geçen örnek üzerinden herhangi bir karşılaştırma yapmadan binanın sürdürülebilirliğini değerlendirmiştir [15].

- Çakır Kıasıf (2019) tarafından yapılan çalışmada, İstanbul'daki LEED sertifikalı yükseköğretim yapıları tüm kriterler üzerinden ele alınmış ve binaların aldığı puanlar üzerinden bir karşılaştırma yapılarak sürdürülebilir stratejilerin güçlü ve zayıf yönlerini ortaya koymuştur [16].

- Akıner ve Akıner (2020)'in çalışması incelendiğinde belgelendirilmemiş bir örnek olay üzerinden Atatürk Orman Çiftliğinin kuruluş döneminin LEED değerlendirme sistemi ile ele alındığı görülmüştür [17].

- Çakır Kıasıf (2020)’ın ele aldığı araştırma makalesinde, İstanbul'daki LEED Sertifikalı Otel Projelerini Su Etkinliği Kriteri açısından değerlendirdiği, karşılaştırdığı ve önerilerde bulunduğu görülmüştür.

\section{MASLAK’TAKİ LEED SERTIFIKKALI OFIS BİNALARININ ENERJİ VE ATMOSFER KRITERİ PERFORMANSI}

Maslak, İstanbul'un Sarıer ilçesinde yer alan ve günümüzle sıklıkla yüksek yapıları ile gündeme gelmekte olan bir bölgedir. Bölgede ulusal ve uluslararası şirketlerin yönetim merkezleri (ofisleri), rezidans, üniversite ve hastane gibi işlevlere sahip birçok LEED sertifikalı bina yer almaktadır.
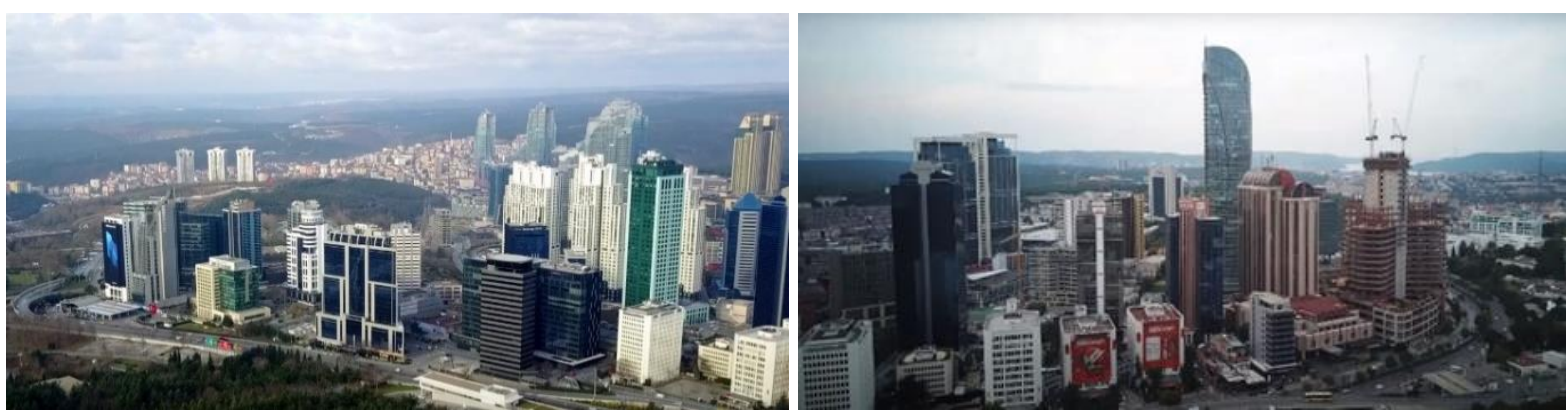

Şekil 4. Maslak Bölgesi’ndeki yüksek yapılar [18]

Maslak bölgesinde, LEED sertifikasyon sürecini tamamlamış 17 adet proje bulunmaktadır. Bu anlamda bölgenin, enerji ve atmosfer kriterinin değerlendirilebilmesi açısından araştırma kapsamında değerlendirilmesi 
uygun görülmüştür. Bölgede yer alan LEED sertifikalı binalar, bunların proje tipleri, sertifikasyon sürecine dahil oldukları yapı türleri, elde ettikleri puanlar, dereceler ve kullanılan sistem versiyonları, Tablo 4 'te verildiği gibidir:

Tablo 4. Maslak Bölgesindeki LEED Sertifikalı Binalar

\begin{tabular}{|c|c|c|c|c|c|c|}
\hline & Projenin Adı & Proje Tipi & LEED Yapı Türü & $\begin{array}{l}\text { LEED } \\
\text { Ver. }\end{array}$ & Puanı & $\begin{array}{l}\text { Sertifika } \\
\text { Türü }\end{array}$ \\
\hline 1. & JLL TURKEY HQ & Ofis & Commercial Interrior & v2009 & 84 & Platinum \\
\hline 2. & OLIVE PLAZA & Ofis & Core and Shell & v2009 & 61 & Gold \\
\hline 3. & $\begin{array}{l}\text { AĞAOĞLU MASLAK } 1453 \\
\text { C BLOK }\end{array}$ & Rezidans & New Construction & v2009 & 61 & Gold \\
\hline 4. & GROUPAMA PLAZA & Ofis & $\begin{array}{l}\text { Existing Buildings } \\
\text { Operations and Maintenance }\end{array}$ & v2009 & 61 & Gold \\
\hline 5. & $\begin{array}{l}\text { DELOITTE MASLAK NO/1 } \\
\text { OFFICE }\end{array}$ & Ofis & Commercial Interiors & v2009 & 63 & Gold \\
\hline 6. & BAXTER TURKEY HQ & Ofis & Commercial Interiors & v2009 & 58 & Silver \\
\hline 7. & $\begin{array}{l}\text { AĞAOĞLU MASLAK } 1453 \\
\text { A BLOK }\end{array}$ & Rezidans & New Construction & v2009 & 60 & Gold \\
\hline 8. & MASLAK LINK PLAZA & Ofis & Core and Shell & v2009 & 65 & Gold \\
\hline 9. & $\begin{array}{l}\text { ACIBADEM MASLAK } 2 . \\
\text { ETAP HASTANESI }\end{array}$ & Hastane & Healthcare & $\mathrm{v} 4$ & 60 & Gold \\
\hline 10. & ALSAR MASLAK NO 1 & Ofis & Core and Shell & v2009 & 67 & Gold \\
\hline 11. & SPINE MASLAK & Rezidans & Core and Shell & v2009 & 64 & Gold \\
\hline 12. & $\begin{array}{l}\text { ERNST YOUNG İSTANBUL } \\
\text { OFFICE }\end{array}$ & Ofis & Commercial Interiors & v2009 & 67 & Gold \\
\hline 13. & BAT İSTANBUL OFFICE & Ofis & Commercial Interiors & v2009 & 81 & Platinum \\
\hline 14. & UNIQ ISTANBUL & $\begin{array}{l}\text { Ofis / } \\
\text { Kültür } \\
\text { Merkezi }\end{array}$ & Core and Shell & v2009 & 57 & Silver \\
\hline 15. & ORJIN MASLAK & Ofis & Core and Shell & v2009 & 65 & Gold \\
\hline 16. & $\begin{array}{l}\text { AĞAOGLU MASLAK } 1453 \\
\text { UNIVERSITY }\end{array}$ & Eğitim & New Construction & v2009 & 60 & Gold \\
\hline 17. & $\begin{array}{l}\text { AĞAOĞLU MASLAK } 1453 \\
\text { B BLOCK }\end{array}$ & Rezidans & New Construction & v2009 & 63 & Gold \\
\hline
\end{tabular}

İlgili binaların sağlıklı bir zeminde değerlendirilebilmesi için bölge (Maslak) sınırlaması yeterli görülmemektedir. Enerji ve atmosfer kriteri bakımından karşılaştırılacak olan binaların öncelikle işlevleri, LEED tarafından değerlendirilmeye tabi tutulduğu yapı türleri ve değerlendirilen LEED sistem versiyonları bakımından aynı paydada yer almaları önem taşımaktadır. Bu nedenle, yalnızca Maslak Bölgesi'nde yer alan 'ofis' işlevine sahip olan ve LEED Core and Shell (Çekirdek+Kabuk) yapı türünde değerlendirilen binalar araştırma kapsamına dahil edilmiştir. 


\section{V.BULGULAR}

Maslak Bölgesinde bulunan 17 adet LEED sertifikasına sahip proje arasından v2009 Core and Shell ofis yapıları tarandığında 5 adet örneğe rastlanılmıştır. Alsar Maslak No:1, Orjin Maslak, Maslak Link Plaza, Olive Plaza ve Uniq İstanbul adlı bu 5proje, sisteme kayıt tarihleri, sertifika tarihleri ve brüt metrekare değerleri ile birlikte Tablo 5'te gösterilmiştir.Bulguların analizinde faydalanılan projelere ait puanlar LEED'in resmi web sitesinden (https://www.usgbc.org/projects) çekilmiş ve her bir projeye ait skor kartları incelenmiştir. Bu skor kartlarında belirtilen 7 adet kriter üzerinden aldığı puan dağılımları Tablo.6'da gösterilmiş ve çalışma kapsamında Enerji ve Atmosfer kriteri değerlendirmeye alınmıştır.

Tablo 5. Maslak Bölgesindeki LEED sertifikalı binalar

\begin{tabular}{|c|c|c|c|c|c|c|c|c|c|}
\hline & Projenin Adı & Proje Tipi & $\begin{array}{c}\text { LEED } \\
\text { Yapı Türüu }\end{array}$ & $\begin{array}{c}\text { LEED } \\
\text { Ver. }\end{array}$ & Puanı & $\begin{array}{l}\text { Sertifika } \\
\text { Türü }\end{array}$ & $\begin{array}{c}\text { Sertifika } \\
\text { Tarihi }\end{array}$ & $\begin{array}{l}\text { Kayıt } \\
\text { Tarihi }\end{array}$ & $\begin{array}{c}\text { Brüt } \\
\text { Metrekare }\end{array}$ \\
\hline 1. & $\begin{array}{l}\text { ALSAR } \\
\text { MASLAK } \\
\text { NO } 1\end{array}$ & Ofis & $\begin{array}{l}\text { Core and } \\
\text { Shell }\end{array}$ & v2009 & 67 & Gold & $5 / 7 / 15$ & $10 / 18 / 11$ & 230477 \\
\hline 2. & $\begin{array}{l}\text { ORJIN } \\
\text { MASLAK }\end{array}$ & Ofis & $\begin{array}{l}\text { Core and } \\
\text { Shell }\end{array}$ & v2009 & 65 & Gold & $4 / 24 / 15$ & $10 / 18 / 11$ & 594881 \\
\hline 3. & $\begin{array}{l}\text { MASLAK } \\
\text { LINK } \\
\text { PLAZA }\end{array}$ & Ofis & $\begin{array}{l}\text { Core and } \\
\text { Shell }\end{array}$ & v2009 & 65 & Gold & $9 / 20 / 16$ & $5 / 31 / 13$ & 206236 \\
\hline 4. & $\begin{array}{l}\text { OLIVE } \\
\text { PLAZA }\end{array}$ & Ofis & $\begin{array}{l}\text { Core and } \\
\text { Shell }\end{array}$ & v2009 & 61 & Gold & $2 / 23 / 12$ & $7 / 19 / 10$ & 113015 \\
\hline 5. & $\begin{array}{l}\text { UNIQ } \\
\text { ISTANBUL }\end{array}$ & $\begin{array}{l}\text { Ofis / Kültür } \\
\text { Merkezi }\end{array}$ & $\begin{array}{l}\text { Core and } \\
\text { Shell }\end{array}$ & v2009 & 57 & Silver & $9 / 18 / 15$ & $9 / 26 / 11$ & 1043929 \\
\hline
\end{tabular}

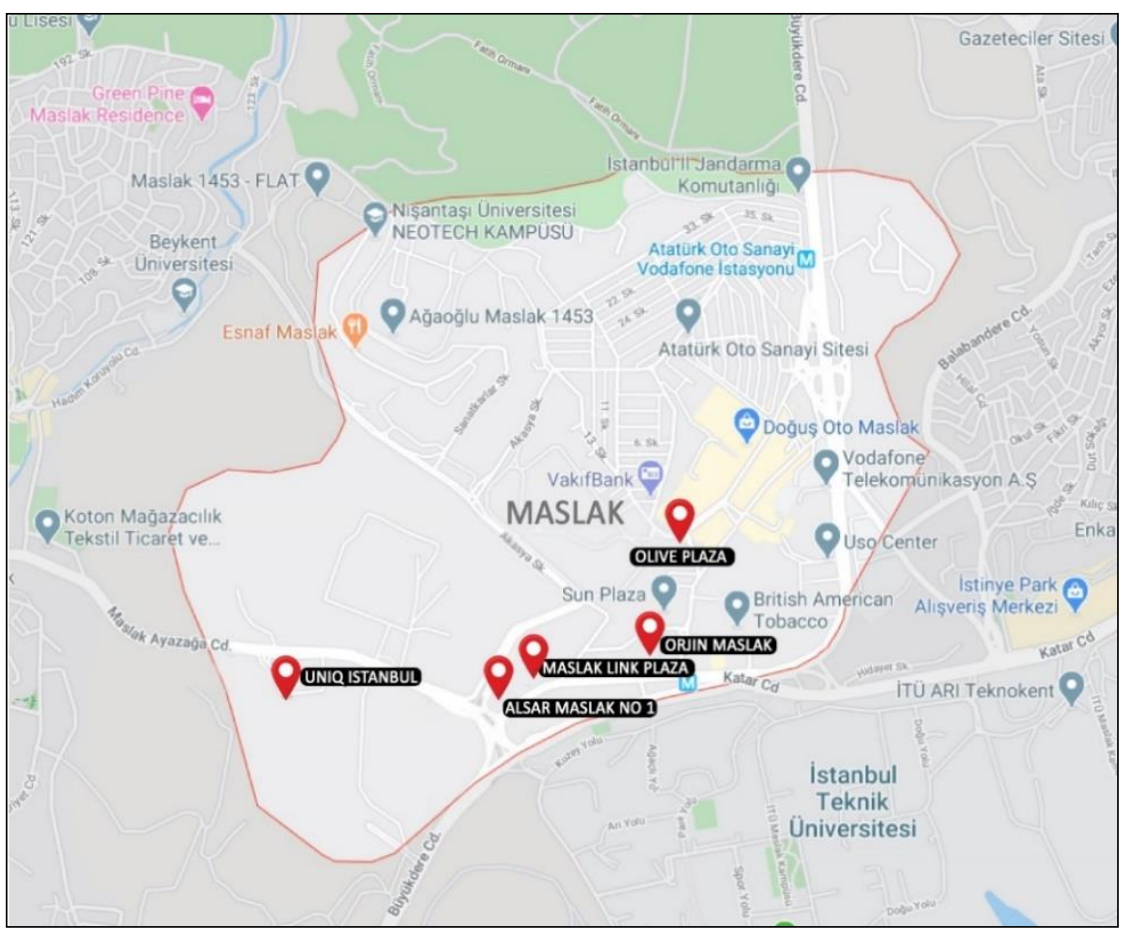

Şekil 5. Maslak Bölgesi ve LEED C+S (Bina ve Kabuk) sertifikalı ofis binalarının konumları 
Aynı LEED versiyonu (v2009 - 3.0) üzerinden değerlendirilen bu 5 projenin 4'ünün Gold derecesine, birinin ise Silver derecesi sahip olduğu görülmektedir. İlgili projelerin 110 tam puan üzerinden tüm kriterler açısından aldıkları puanlar, Tablo 6'da verilmiştir.

Tablo 6. Belirlenen binaların LEED puan dağılımları

\begin{tabular}{|c|c|c|c|c|c|}
\hline & $\begin{array}{c}\text { ALSAR MASLAK } \\
\text { NO } 1 \\
\text { Aldığı Puan }\end{array}$ & $\begin{array}{c}\text { ORJIN } \\
\text { MASLAK } \\
\text { Aldığı Puan }\end{array}$ & $\begin{array}{c}\text { MASLAK LINK } \\
\text { PLAZA } \\
\text { Aldığı Puan }\end{array}$ & $\begin{array}{c}\text { OLIVE } \\
\text { PLAZA } \\
\text { Aldığı Puan }\end{array}$ & $\begin{array}{c}\text { UNIQ } \\
\text { ISTANBUL } \\
\text { Aldığı Puan }\end{array}$ \\
\hline $\begin{array}{l}\text { 1. Sürdürülebilir } \\
\text { Araziler }\end{array}$ & $(24 / 28)$ & $(21 / 28)$ & $(22 / 28)$ & $(24 / 28)$ & $(21 / 28)$ \\
\hline 2. Su Verimliliği & $(8 / 10)$ & $(7 / 10)$ & $(10 / 10)$ & $(8 / 10)$ & $(8 / 10)$ \\
\hline 3. Enerji ve Atmosfer & $(16 / 37)$ & $(18 / 37)$ & $(16 / 37)$ & $(8 / 37)$ & $(16 / 37)$ \\
\hline $\begin{array}{l}\text { 4. Malzeme ve } \\
\text { Kaynaklar }\end{array}$ & $(6 / 13)$ & $(4 / 13)$ & $(4 / 13)$ & $(5 / 13)$ & $(2 / 13)$ \\
\hline 5. İç Ortam Kalitesi & $(4 / 12)$ & $(6 / 12)$ & $(6 / 12)$ & $(8 / 12)$ & $(1 / 12)$ \\
\hline 6. İnovasyon & $(5 / 6)$ & $(5 / 6)$ & $(4 / 6)$ & $(6 / 6)$ & $(5 / 6)$ \\
\hline 7. Bölgesel Öncelik & $(4 / 4)$ & $(4 / 4)$ & $(4 / 4)$ & $(2 / 4)$ & $(4 / 4)$ \\
\hline Toplam Puan / Skor & $67 / 110$ & $65 / 110$ & $65 / 110$ & $61 / 110$ & $57 / 110$ \\
\hline Sertifika Türü & LEED Gold & LEED Gold & LEED Gold & LEED Gold & LEED Silver \\
\hline
\end{tabular}

Orjin Maslak, toplam puan bakımından ikinci sırada bulunmasına karşın (birinci sırada 67 puan ile Maslak No 1), 37 puan üzerinden 18 puan ile Enerji ve Atmosfer kriteri bakımından birinci sıradadır. Alsar Maslak No 1, Maslak Link Plaza ve Uniq İstanbul projelerinin 16 puan ile ikinci sirada ve Olive Plaza'nın 8 puan ile son sırada yer aldığı Tablo 6'da görülmektedir. Enerji ve Atmosfer kategorisinde aynı puana sahip olmalarına karşın, projelerin alt kredilerindeki puan dağılımlarında değişiklikler görülmektedir. Bu nedenle, belirlenen binaların, enerji ve atmosfer kriterini oluşturan alt kredilerinden elde ettikleri puanlar ve başarı yüzdeleri Tablo 7'de çözümlenmiştir. Tablo 7 incelendiğinde Enerji ve Atmosfer kriterine ait 3 ön koşul ve 7 adet de kredinin olduğu görülmektedir. 1.Ön Koşul, Temel Bina Enerji Sistemlerinin Kullanılması, 2.Ön Koşul, Minimum Enerji Performans1, 3.Ön Koşul, Temel Soğutma Yöntemi, Kredi 1, Enerji Performansı Optimizasyonu, Kredi 2, Yerinde Yenilenebilir Enerji Kullanımı, Kredi 3 Gelişmiş Yapılandırma, Kredi 4 Gelişmiş Soğutma Yönetimi, Kredi 5.1 Temel Binada Ölçüm ve Onaylama, Kredi 5.2 Kiracı Alt Ölçümü kapsamında Ölçüm ve Onaylama, Kredi 6 Yeşil Güç Kullanımı stratejilerinden oluşmaktadır. 
Tablo 7. Belirlenen binaların enerji ve atmosfer kriteri bakımından puanları

\begin{tabular}{|c|c|c|c|c|c|c|c|c|c|c|c|}
\hline & & \multicolumn{2}{|c|}{$\begin{array}{c}\text { ALSAR MASLAK } \\
\text { NO } 1\end{array}$} & \multicolumn{2}{|c|}{$\begin{array}{c}\text { ORJIN } \\
\text { MASLAK }\end{array}$} & \multicolumn{2}{|c|}{$\begin{array}{l}\text { MASLAK LINK } \\
\text { PLAZA }\end{array}$} & \multicolumn{2}{|c|}{ OLIVE PLAZA } & \multicolumn{2}{|c|}{ UNIQ ISTANBUL } \\
\hline & & Puan & $\begin{array}{c}\text { Başarı } \\
(\%) \\
\end{array}$ & Puan & $\begin{array}{c}\text { Başarı } \\
(\%) \\
\end{array}$ & Puan & $\begin{array}{c}\text { Başarı } \\
(\%)\end{array}$ & Puan & $\begin{array}{c}\text { Başarı } \\
(\%) \\
\end{array}$ & Puan & $\begin{array}{c}\text { Başarı } \\
(\%)\end{array}$ \\
\hline$\ddot{O} n$ & Temel Bina & \multirow{2}{*}{\multicolumn{2}{|c|}{ Zorunlu }} & \multirow{2}{*}{\multicolumn{2}{|c|}{ Zorunlu }} & \multirow{2}{*}{\multicolumn{2}{|c|}{ Zorunlu }} & \multirow{2}{*}{\multicolumn{2}{|c|}{ Zorunlu }} & \multirow{2}{*}{\multicolumn{2}{|c|}{ Zorunlu }} \\
\hline $\begin{array}{l}\text { Koşul } \\
1\end{array}$ & $\begin{array}{l}\text { Enerji Sis. } \\
\text { Kullanılması }\end{array}$ & & & & & & & & & & \\
\hline $\begin{array}{l}\ddot{O n} \\
\text { Koşul } \\
2\end{array}$ & $\begin{array}{l}\text { Minimum Enerji } \\
\text { Performansl }\end{array}$ & \multicolumn{2}{|c|}{ Zorunlu } & \multicolumn{2}{|c|}{ Zorunlu } & \multicolumn{2}{|c|}{ Zorunlu } & \multicolumn{2}{|c|}{ Zorunlu } & \multicolumn{2}{|c|}{ Zorunlu } \\
\hline $\begin{array}{l}\ddot{O n} \\
\text { Koşul } \\
3\end{array}$ & $\begin{array}{l}\text { Temel Soğutma } \\
\text { Yönetimi }\end{array}$ & \multicolumn{2}{|c|}{ Zorunlu } & \multicolumn{2}{|c|}{ Zorunlu } & \multicolumn{2}{|c|}{ Zorunlu } & \multicolumn{2}{|c|}{ Zorunlu } & \multicolumn{2}{|c|}{ Zorunlu } \\
\hline Kredi 1 & $\begin{array}{l}\text { Enerji Performans } \\
\text { Opt. }\end{array}$ & $(12 / 21)$ & $57 \%$ & $(8 / 21)$ & $38 \%$ & $(6 / 21)$ & $29 \%$ & $(\mathbf{0} / 21)$ & $0 \%$ & $(10 / 21)$ & $48 \%$ \\
\hline Kredi 2 & $\begin{array}{l}\text { Yerinde } \\
\text { Yenilenebilir } \\
\text { Enerji }\end{array}$ & $(0 / 4)$ & $0 \%$ & $(0 / 4)$ & $0 \%$ & $(0 / 4)$ & $0 \%$ & $(0 / 4)$ & $0 \%$ & $(0 / 4)$ & $0 \%$ \\
\hline Kredi 3 & $\begin{array}{l}\text { Gelişmiş } \\
\text { Yapılandırma } \\
\text { Gelișmis }\end{array}$ & $(2 / 2)$ & $100 \%$ & $(2 / 2)$ & $100 \%$ & $(2 / 2)$ & $100 \%$ & $(0 / 2)$ & $0 \%$ & $(0 / 2)$ & $0 \%$ \\
\hline Kredi 4 & $\begin{array}{l}\text { Soğutma } \\
\text { Yönetimi }\end{array}$ & $(2 / 2)$ & $100 \%$ & $(2 / 2)$ & $100 \%$ & $(2 / 2)$ & $100 \%$ & $(2 / 2)$ & $100 \%$ & $(0 / 2)$ & $0 \%$ \\
\hline $\begin{array}{l}\text { Kredi } \\
5.1\end{array}$ & $\begin{array}{l}\text { Ölçüm ve } \\
\text { Onaylama - } \\
\text { Temel Bina }\end{array}$ & $(0 / 3)$ & $0 \%$ & $(3 / 3)$ & $100 \%$ & $(\mathbf{3} / 3)$ & $100 \%$ & $(3 / 3)$ & $100 \%$ & $(3 / 3)$ & $100 \%$ \\
\hline $\begin{array}{l}\text { Kredi } \\
5.2\end{array}$ & $\begin{array}{l}\text { Ölçüm ve } \\
\text { Onaylama - Kiracı } \\
\text { Alt Ölçümü }\end{array}$ & $(0 / 3)$ & $0 \%$ & $(3 / 3)$ & $100 \%$ & $(\mathbf{3} / 3)$ & $100 \%$ & $(3 / 3)$ & $100 \%$ & $(3 / 3)$ & $100 \%$ \\
\hline Kredi 6 & Yeşil Güç & $(0 / 2)$ & $100 \%$ & $(0 / 2)$ & $0 \%$ & $(0 / 2)$ & $0 \%$ & $(0 / 2)$ & $0 \%$ & $(0 / 2)$ & $0 \%$ \\
\hline E.A. & Kriter Toplamı & $16 / 37$ & $43 \%$ & $18 / 37$ & $48 \%$ & $16 / 37$ & $43 \%$ & 8/37 & $22 \%$ & $16 / 37$ & $43 \%$ \\
\hline
\end{tabular}

Çalışma kapsamında değerlendirilen tüm yapılar, sertifikasyon sürecini tamamlamış, dolayısı ile enerji ve atmosfer kategorisindeki ön koşulları yerine getirmişlerdir. Ancak diğer krediler söz konusu olduğunda bina bazında farklı başarı yüzdeleri olduğu da görülmektedir.

Alsar Maslak No 1, 21 puanlık enerji performansının optimize edilmesi kredisinden 12 puan alarak \%57'lik bir başarı sağlamış ve bu krediden en başarılı sonucu elde eden bina olmuştur. Dört puanlık yerinde yenilenebilir enerji kredisinden ve 3'er puanlık ölçüm ve onaylama kredilerinden ise hiç puan alamayarak başarısız olmuştur. Bunlarla birlikte, her biri 2'şer puanlık olan gelişmiş yapılandırma, gelişmiş soğutma yönetimi ve yeşil güç kredilerinin her birinden tam puan alarak \%100'lük bir başarı elde etmiştir. Ayrıca, Alsar Maslak No 1, yeşil güç kredisinden puan alabilen tek bina olmuştur. Böylece bina, toplamda 37 puanlık enerji ve atmosfer kriterinden 16 puan alarak \% 43 'lük bir başarı oranı elde etmiştir.

Orjin Maslak, 21 puanlık enerji performansının optimize edilmesi kredisinden 8 puan alarak \%38'lik bir başarı oranı elde etmiştir. Dört puanlı yerinde yenilenebilir enerji kredisinden ve 2 puanlık yeşil güç kredisinden hiç puan alamayarak başarısız olmuştur. Ancak bina geriye kalan 3'er puanlık ölçüm ve onaylama kredilerinden ve bunlarla birlikte, her biri 2'şer puanlık olan gelişmiş yapılandırma ve gelişmiş soğutma yönetimi kredilerinin her birinden tam puan alarak \%100'lük bir başarı oranı elde etmiştir. Böylece Orjin Maslak toplamda 37 puanlık enerji ve atmosfer kriterinden 18 puan alarak \%48'lik bir başarı oranı elde etmiş ve incelenen binalar arasında bu kategorideki en başarılı bina olmuştur.

Maslak Link Plaza, 21 puanlık enerji performansının optimize edilmesi kredisinden 6 puan alarak \%29'luk bir başarı oranı elde etmiştir. Ancak, 4 puanlık yerinde yenilenebilir enerji kredisinden ve 2 puanlık yeşil güç kredisinden hiç puan alamayarak başarısız olmuştur. Geriye kalan 3'er puanlık ölçüm ve onaylama kredilerinden ve bunlarla birlikte, her biri 2'şer puanlık olan gelişmiş yapılandırma ve gelişmiş soğutma yönetimi kredilerinin her birinden Orjin Maslak binasıyla benzer bir şekilde tam puan alarak \%100'lük bir başarı elde etmiştir. Böylece Maslak Link Plaza, toplamda 37 puanlık enerji ve atmosfer kriterinden 16 puan alarak \% 43 'lük bir başarı oranı elde etmiştir. 


\begin{tabular}{|c|c|c|}
\hline & $\begin{array}{l}\text { BŞEÜ Fen Bilimleri Dergisi } \\
8(1), 322-335,2021\end{array}$ & $\begin{array}{r}\text { BSEU Journal of Science } \\
\text { https://doi.org/10.35193/bseufbd.887581 }\end{array}$ \\
\hline $\begin{array}{l}\text { BiLECEIK SEYH EDEBALI } \\
\text { UNIVERSITESI }\end{array}$ & & 2458-7575 (https://dergipark.org.tr/tr/pub/bseufbd) \\
\hline
\end{tabular}

Olive Plaza, 21 puanlık enerji performansının optimize edilmesi kredisinden hiç puan alamayarak, değerlendirilen yapılar arasında bu krediden başarısız olan tek bina olmuştur. Bina aynı zamanda 4 puanlık yerinde yenilenebilir enerji kredisinden, 2 puanlık gelişmiş yapılandırma kredisinden, 2 puanlık da yeşil güç kredisinden de puan alamamış ve böylelikle \%0'lık bir başarı oranı elde etmiştir. Buna rağmen, geriye kalan 3'er puanlık ölçüm ve onaylama kredilerinden ve 2 puanlık olan geliş̧iş soğutma yönetimi kredilerinin her birinden tam puan alarak \%100'lük bir başarı oranı elde etmiştir. Olive Plaza, krediler arasında en yüksek puana sahip olan enerji performansının optimize edilmesi kredisinden ve diğer kredilerden kaybettiği puanlar neticesinde, toplamda 37 puanlık enerji ve atmosfer kriterinden yalnızca 8 puan alarak \%22'lik bir başarı oranı elde etmiştir. Bu oran, binanın incelenen yapılar arasında, enerji ve atmosfer kriteri bakımından en başarısız bina olduğunu göstermektedir.

Uniq İstanbul ise, Olive Plaza'nın aksine 21 puanlık enerji performansının optimize edilmesi kredisinden 10 puan alarak \% $48^{\prime}$ lik bir başarı oranı sağlamıștır. Ancak, 4 puanlık yerinde yenilenebilir enerji kredisinden, her biri 2'şer puanlık gelişmiş yapılandırma, gelişmiş soğutma yönetimi ve yeşil güç kredilerinden puan alamamış ve başarısız olmuştur. Geriye kalan 3'er puanlık ölçüm ve onaylama kredilerinden ise tam puan alarak \%100'lük bir başarı elde etmiştir. Uniq İstanbul, toplamda 37 puanlık enerji ve atmosfer kriterinden 16 puan alarak \%43'lük bir başarı oranı elde etmiştir.

Böylece, incelenen yapılar arasında, Orjin Maslak'ın enerji ve atmosfer kriteri bakımından en başarıll, Olive Plaza'nın ise en başarısız bina olduğu, Alsar Maslak No 1, Maslak Link Plaza ve Uniq İstanbul'un ise başarı sıralamasında ikinci sırayı paylaştı̆ı söylenebilmektedir.

Maslak Bölgesinde yer alan LEED sertifikalı ofis yapılarının elde ettikleri başarı oranlarının kategorinin alt kredileri bakımından karş̧laştırılması, bölgede yer alan binaların ilgili kredilerdeki eksikliklerinin ortaya çıkarılması bakımından ayrıca önem taşımaktadır. Bu nedenle, Enerji ve Atmosfer kriterini oluşturan her bir kredinin binalardaki başarı oranları ve genel ortalamaları Tablo 8'de verilmektedir:

Tablo 8. Binaların, enerji ve atmosfer kriterinin alt kredilerindeki başarı oranları

\begin{tabular}{|c|c|c|c|c|c|c|c|}
\hline & & $\begin{array}{c}\text { ALSAR } \\
\text { MASLAK NO } \\
\mathbf{1} \\
\end{array}$ & $\begin{array}{c}\text { ORJIN } \\
\text { MASLAK }\end{array}$ & $\begin{array}{c}\text { MASLAK } \\
\text { LINK } \\
\text { PLAZA }\end{array}$ & $\begin{array}{l}\text { OLIVE } \\
\text { PLAZA }\end{array}$ & $\begin{array}{c}\text { UNIQ } \\
\text { ISTANBUL }\end{array}$ & $\begin{array}{l}\text { BİNA } \\
\text { ORT. }\end{array}$ \\
\hline & & $\begin{array}{c}\text { Başarı } \\
(\%)\end{array}$ & $\begin{array}{c}\text { Başarı } \\
(\%)\end{array}$ & $\begin{array}{c}\text { Başarı } \\
(\%) \\
\end{array}$ & $\begin{array}{c}\text { Başarı } \\
(\%) \\
\end{array}$ & $\begin{array}{c}\text { Başarı } \\
(\%) \\
\end{array}$ & $\begin{array}{r}\text { Başar1 } \\
(\%) \\
\end{array}$ \\
\hline K1 & $\begin{array}{l}\text { Enerji Performansının } \\
\text { Optimize Edilmesi }\end{array}$ & $57 \%$ & $38 \%$ & $29 \%$ & $0 \%$ & $48 \%$ & $34 \%$ \\
\hline K2 & $\begin{array}{l}\text { Yerinde Yenilenebilir } \\
\text { Enerji }\end{array}$ & $0 \%$ & $0 \%$ & $0 \%$ & $0 \%$ & $0 \%$ & $0 \%$ \\
\hline K3 & Gelişmiş Yapılandırma & $100 \%$ & $100, \%$ & $100 \%$ & $0 \%$ & $0 \%$ & $60 \%$ \\
\hline K4 & $\begin{array}{l}\text { Gelişmiş Soğutma } \\
\text { Yönetimi }\end{array}$ & $100 \%$ & $100 \%$ & $100 \%$ & $100 \%$ & $0 \%$ & $80 \%$ \\
\hline K5.1 & $\begin{array}{l}\text { Ölçüm ve Onaylama - } \\
\text { Temel Bina }\end{array}$ & $0 \%$ & $100 \%$ & $100 \%$ & $100 \%$ & $100 \%$ & $80 \%$ \\
\hline K5.2 & $\begin{array}{l}\text { Ölçüm ve Onaylama - } \\
\text { Kiracı Alt Ölçümü }\end{array}$ & $0 \%$ & $100 \%$ & $100 \%$ & $100 \%$ & $100 \%$ & $80 \%$ \\
\hline K6 & Yeşil Güç & $100 \%$ & $0 \%$ & $0 \%$ & $0 \%$ & $0 \%$ & $20 \%$ \\
\hline \multicolumn{2}{|c|}{ Enerji ve Atmosfer Kriteri } & $43 \%$ & $48 \%$ & $43 \%$ & $22 \%$ & $43 \%$ & $40 \%$ \\
\hline
\end{tabular}

Tablo 8'e göre, Enerji Performansının Optimize Edilmesi kredisi bakımından, incelenen tüm binaların elde ettiği başarı ortalamasının \%34 olduğu görülmektedir. Yerinde Yenilenebilir Enerji bakımından ise hiçbir bina puan alamayarak ortalamada $\% 0^{\prime}$ lık bir başarı oranı elde edilmiş̧ir. Binalar, Gelişmiş Yapılandırma kredisi bakımından ortalamada \%60 başarı sağlamışlardır. Gelişmiş Soğutma Yönetimi ve Ölçüm ve Onaylama Kredilerinin ise \%80'lik bir oran ile binaların en başarılı ortalamaya sahip olduğu ifade edilebilmektedir. Yeşil 
Güç kriteri bakımından ise ortalamada \%20'lik bir başarı söz konusudur. Genel anlamda tüm binaların, enerji ve atmosfer kriteri bakımından ortalamada \%40’lık bir başarıya sahip olduğu söylenebilir.

\section{SONUCLAR}

Küresel anlamda enerji tüketiminin ve zararlı madde salınımının büyük bir kısmına neden olan yapı sektörü için, enerji ve atmosfer kriteri çevresel etkilerinin başında gelmektedir. Bu anlamda, LEED’in yapıların enerji ve atmosfer kriteri bakımından sürdürülebilirliklerini ölçmek için geliştirdiği krediler önem taşımaktadır. Enerji Performansının Optimize Edilmesi, Yerinde Yenilenebilir Enerji, Gelişmiş Yapılandırma, Gelişmiş Soğutma Yönetimi, Ölçüm ve Onaylama - Temel Bina, Ölçüm ve Onaylama - Kiracı Alt Ölçümü ve Yeşil Güç başlıklarını içeren bu krediler, binaların enerji ve atmosferle ilgili birçok etkileşiminin sayısal olarak ölçülebilmesine olanak sağlamaktadır. Yüksek yapıları ile bilinen Maslak Bölgesi'nde birçok LEED sertifikalı ofis binası yer almaktadır. Çalışmada, bu binalar arasında LEED'in Çekirdek ve Kabuk yapı türünde yer alan ofis binaları, ilgili kredilerden elde ettikleri puanlar ve başarılar bağlamında değerlendirilmiştir.

Yapılan değerlendirmeler sonucunda, yerinde yenilenebilir enerji kullanımının \%0 oranı ile en başarısız kredi alanı olduğu belirlenmiştir. Bu anlamda, yenilebilir enerji kullanımının tüm binalarda sağlanması ve üretilen enerjinin binanın y1llık enerji maliyetinin büyük bir kısmını oluşturacak şekilde planlama yapılması önerilmektedir. Yerinde yenilenebilir enerji kullanımındaki başarısızlığı, yeşil güç kredisi takip etmektedir. Binaların yeşil güç başarı ortalaması \%20 olmasına karşın, aslında bu başarının tamamen Alsar Maslak No 1'den kaynaklandığ 1 görülmektedir. Alsar Maslak No 1, bu krediden tam puan alarak \%100 başarı elde etmiş, diğer binalar ise tamamen başarısız olmuşlardır. Bu nedenle, Orjin Maslak, Maslak Link Plaza, Olive Plaza ve Uniq İstanbul binalarının enerji ihtiyaçlarının \%35'lik bir kısmını iki yıl boyunca yeşil enerji üretebilen kaynaklardan sağlaması önerilmektedir. Enerji Performansının optimize edilmesi, bu kategorideki en çok puana sahip olmasına rağmen binaların bu kredideki ortalama başarı oranları \%34 olarak belirlenmiştir. Bina bazında değerlendirildiğinde, \%57 oranı ile en başarılı bina Alsar Maslak No 1 olurken, Olive Plaza'nın bu krediden hiç puan alamadığı görülmüştür. Diğer binalar ise çeşitli başarı seviyeleri ile sistemde yer almıştır. Binaların, dış kabuk, havalandırma unsurları, güç dağıtım ve aydınlatma sistemlerinin geliştirilerek, daha performanslı bir enerji simülasyonu oluşturulması önerilmektedir. Bu krediden elde edilebilecek puanlar, sahip olduğu ağırlıklı puan bakımından, bina toplam puanlarını doğrudan etkileyebilecek, hatta binaların dereceleri yükselebilecektir. Gelişmiş yapılandırma kriteri bakımından, Alsar Maslak No 1, Orjin Maslak ve Maslak Link Plaza'nın \%100 başarı sağladığı ancak Olive Plaza ve Uniq İstanbul binalarının tamamen başarısız olduğu söylenebilmektedir. Bu anlamda, Olive Plaza ve Uniq İstanbul binaları için enerji sistemi tasarımlarının incelenmesi, yapı operatörleri için elle kontrol edilebilen sistemler oluşturulması, çalışanların eğitiminin ve performansının doğrulanabilmesi için yaklaşık bir yıllık bir süre için yapı operasyonlarının yeniden denetlenerek yapılandırmanın geliştirilmesi önerilmektedir. Gelişmiş Soğutma Yönetimi bakımından Uniq İstanbul hariç tüm binaların \%100 başarı elde ettikleri görülmektedir. Bu kriter kapsamında, Uniq İstanbul binası için, ozon tabakasına zarar verebilecek madde salınımlarının öncelikle azaltılması ve zamanla tamamen ortadan kaldırılması için gerekli adımların atılması önerilmektedir. Son olarak, ölçüm ve onaylama kriteri bakımından hem temel bina ölçümünde hem de kiracı alt ölçümünde, Alsar Maslak No 1 hariç tüm binaların \%100'lük başarı elde ettikleri görülmektedir. Bu kapsamda, Alsar Maslak No 1 binası için, projelendirme sürecinde belirlenen tüketim miktarlarının yakalanabilmesine yönelik adımlar atılması veya gerekli ölçümlerin yapılabilmesine yönelik bir sensör sistemi oluşturulması önerilmektedir.

Türkiye'de enerji etkin binaların sayılarının artması ülke kalkınması için çok önemli bir husustur. Bu yüzden enerji etkin stratejilerin yapılar üzerinde uygulanmasında teşviklerin arttırılması gerekmektedir. Yatırım yeri tahsisi, vergi indirimi, KDV istisnası, faiz desteği gibi yöntemler ile verilen teşvikler sayesinde enerji etkin yapıların inşasında ciddi bir artış yaşanacağı ve enerji kaynaklarının çok daha verimli kullanılacağı öngörülmektedir. Yeni inşa edilecek binaların yanı sıra mevcut binaların da enerji ve atmosfer üzerindeki etkilerinin dikkatlice değerlendirilmesi ve ilgili çözümlerin tasarım, yapım ve kullanım aşamalarında ayrı ayrı geliştirilmesi önerilmektedir. İlk olarak binalar, kazandırılacak işleve bağlı olarak gerekli enerji sistemleri ile donatılacak şekilde tasarlanmalı, soğutma sistemlerinden salınan gazların ozon tabakasına zarar vermesi önlenmeli ve minimum enerji harcanarak maksimum verim alınması hedeflenmelidir. Uygulama ise, projelendirme ve tasarım sürecinde belirlenen şartlarda gerçekleştirilmelidir. Ayrıca, tasarım ve uygulama alanındaki uyumsuzlukların ortadan kaldırılabilmesi için, binaların işlevleri ile uyumlu sistemler başta sağlıklı bir biçimde belirlenmelidir. Yerinde yenilenebilir enerji kullanımı ve yeşil güç gibi uzun süreli yatırım gerektiren konularda, gerekli teşviklerin sağlanmasına yönelik idari çalışmaların yürütülmesi ayrıca önemli görülmektedir. LEED, diğer sertifikasyon sistemlerinde olduğu gibi, binaların ne düzeyde sürdürülebilir olduklarının sayısal olarak ölçümüne 
yönelik bir sistem olarak çalışmaktadır. Dolayısı ile yapılan değerlendirmeler ve öneriler göz önünde bulundurularak, sertifikalandırma süreçlerinden daha başarılı sonuçlar elde edebilmek mümkün olacaktır. Ancak, bunun gerçekleşebilmesi için birçok disiplinin kendi içerisinde ve disiplinlerarası düzeyde, insanın enerji ve atmosfer ile olan çevresel etkileşimini göz önünde bulundurarak hareket etmesi gerekmektedir. Çalışma, daha geniş bir alan belirlenerek genişletilebileceği gibi, diğer tüm yapı türleri ve tüm kriterlerin birlikte incelenmesi ile geliştirilebilecektir. Bu kapsamda yapılacak bilimsel çalışmalar başta yalnızca bir farkındalık oluşturabilecek ve belki de zamanla toplumun tüm bireylerine ulaşarak bir kültür haline gelebilecektir.

\section{KAYNAKLAR}

[1] Selçuk, G. (2010). LEED Sertifikası Almaya Yönelik Yeni Bina ve Kapsamlı Yenileme Projelerinde Sözleşmelerin Biçimlendirilmesi. Yüksek Lisans Tezi, İstanbul Teknik Üniversitesi, Fen Bilimler Enstitüsü, İstanbul.

[2] The U.S. Green Building Council, (2021). Projects, https://www.usgbc.org/projects, (15.01.2021).

[3] Çimen, T. (2008). Teknolojik Gelişmelerin Sonucunda Değişen Üretim İlişkilerinin, Ofis Yapılarına Etkisi ve Ofis Mekanları. İstanbul Teknik Üniversitesi Fen Bilimleri Enstitüsü, Yüksek Lisans Tezi.

[4] Köse Doğan, R. (2008). Yönetici Bürolarında Mekan Örgütlenmesi. Doktora Tezi, Selçuk Üniversitesi Fen Bilimleri Enstitüsü, Konya.

[5] Pickard, Q. (2002). The Architects' Handbook, Blackwell Science Ltd., A Blackwell Publishing Company, UK, USA, Australia Germany.

[6] Kohn E. (1990). The Tall Building. Tall Buildings: 2000 and beyond, Fourth World Congress, Hong Kong Convention and Ezhibition Center, Council on Tall buildings and Urban Habitat, editor Lynn S. Beedle, Lehigh university, Bethlehem, Pennsylvania, USA.

[7] Kayan, N. (2009). Çok Katlı Ofis Yapıları ve Açık Ofis Planlama Yaklaşımları/Harmancı Giz Plaza, Sabancı Center, Kanyon Ve Nida Kule Örneklerinde Açık Ofis Planlama Yaklaşımlarının İrdelenmesi. Yüksek Lisans Tezi, Yıldız Teknik Üniversitesi Fen Bilimleri Enstitüsü, İstanbul.

[8] Eryıldız, D. (2003). Sürdürülebilirlik ve Mimarlık Dosyasında Ekolojik Mimarlık. Arredamento Mimarlık Dergisi, 154, 71.

[9] Özcan, U. (2013). Konutlarda Sürdürülebilir Mimarlık Açısından İklimsel Konfor Kriterlerinin Değerlendirilmesi İçin Bir Model Önerisi, Doktora Tezi, Beykent Üniversitesi Fen Bilimleri Enstitüsü, İstanbul.

[10] Çakır Kıasıf, G. (2020). Su Yönetimi ve Yapı Endüstrisindeki Su Etkin Otel Karşılaştırmaları: İstanbul'daki LEED Sertifikalı Sürdürülebilir Otel Karşılaştırmaları, Uluslararası Hakemli Tasarım ve Mimarlık Dergisi, 19, 97-133.

[11] Sev, A. (2009). Sürdürülebilir Mimarlık. 1.Baskı, İstanbul, Türkiye: YEM, 38-43.

[12] Şişecam Düzcam, Yeşil Bina, Yeşil Dünya-Yeşil Binalarda Cam Çözümleri, Retrieved From: https://www.sisecamduzcam.com/tr/Documents/Ye\%C5\%9Fil\%20Binalarda\%20Cam\%20\%C3\%87\%C3\% B6z\%C3\%BCmleri.pdf, , (24.12.2020).

[13] Erdede, S. B. \& Bektaş, S. (2014). Ekolojik Açıdan Sürdürülebilir Taşınmaz Geliştirme ve Yeşil Bina Sertifika Sistemleri, Harita Teknolojileri Elektronik Dergisi, 1, 1-12.

[14] Gürgün, A.P. (2017). Türkiye'deki LEED NC 2009 Sertifikalı Binaların Enerji ve Atmosfer Kredilerinin Değerlendirilmesi, Politeknik Dergisi, 20(2), 383-392.

[15] Saka, İ. (2011). Sürdürülebilirlik Açısından İstanbul'da Bir Ofis Binasının LEED Sertifikalandırma Sistemi Kapsamında Değerlendirilmesi, İstanbul Teknik Üniversitesi Fen Bilimleri Enstitüsü, Yüksek Lisans Tezi.

[16] Çakır Kıasıf, G. (2019). Sürdürülebilir Yükseköğretim Yapıları İstanbul'daki Sürdürülebilir Yükseköğretim Yapılarının LEED Kriterleri Kapsamında Karşılaştırmalı Analizi, Yapı Dergisi, Sayı:448, s.30-39.

[17] Akıner, İ. \& Akıner, M. E. (2020). Leed Sertifikasyon Sistemi Bağlamında Sürdürülebilir Kentleşme Projesi: Atatürk Orman Çiftliği Örneği. Avrupa Bilim ve Teknoloji Dergisi, 19, 850-857.

[18] Alper's World Youtube Kanalı, İstanbul Teknik Üniversitesi Maslak Kampüsü Drone Çekim, Retrieved From: https://www.youtube.com/watch?v=ASxFsWi84bU\&t=94s, (15.12.2020). 